Received: 14.08.2019; Accepted 23.08.2019; published: 30.09.2019 at www.editoncpublishing.org

Ngatia mwangi et al., Editon Cons. J. Arts., Humanit. S. Stud., Double -Blind Peer Reviewed Journal

\title{
Influence of Church Political Activities on Congregation Socioeconomic Development: A Case of P.C.E.A. Molo Parish, Nakuru county-Kenya
}

\author{
Joseph Mwangi Ngatia', Peter Koome², Paul Gesimba \\ ${ }^{123}$ St. Paul's University, Kenya \\ Email address: revjmwangin@gmail.com
}

\begin{abstract}
The purpose of this study was to investigate the influence of church political activities on congregation development at PCEA Molo Parish in Molo Sub-County, Nakuru County in Kenya. The study employed a descriptive design. The population of the study was 1093 individuals comprising of 690 communicants, 390 church groups' leaders, and 13 congregation chairpersons. From this population, 285 respondents comprising of 180 communicants, 102 group leaders, and 3 congregation chairperson were selected using the systematic sampling technique. Questionnaires were used to collect data from communicants and group leaders while interviews schedules were used to collect data from congregation chairpersons. Quantitative data was analysed using inferential and descriptive statistics and presented in the form of graphs and table. Qualitative data was analysed thematically and results reported in quotes and narratives. Findings revealed that the PCEA Molo Parish actively engages in an assortment of political activities including advocating for issues, which are relevant to members, educating members on political issues, promoting peace and reconciliation, shaping policies and laws, and development of values essential to political progress. The overall political activities score was 4.92 out of a possible highest score of 7. The Pearson correlation test indicated that there is a statistically significant positive association between church political activities and congregation socioeconomic development $(r=.418$, $\mathrm{p}=.014)$. The study recommended that the parish consider encouraging members of its congregation to increase their participation in politics and governance issues.
\end{abstract}

Key Terms: Church, Religion, Political activities, Congregation development, Wellbeing

$* * *$

How to cite this article in APA ( $6^{\text {th }}$ Edition)

Ngatia, J. M., Koome, P., \& Gesimba, P. (2019). Influence of church political activities on congregation socioeconomic development: A case of P.C.E.A. Molo Parish, Nakuru county-Kenya. Editon Cons. J.

Arts., Humanit. S. Stud., 1(3), 55-67.

*** 


\section{Editon Consortium Journal of Arts, Humanities and Social Studies (ECJAHSS)}

Volume: 01 Issue: 03 | Sep -2019

ISSN: $2663-8525$

Received: 14.08.2019; Accepted 23.08.2019; published: 30.09.2019 at www.editoncpublishing.org

Ngatia mwangi et al., Editon Cons. J. Arts., Humanit. S. Stud., Double -Blind Peer Reviewed Journal

\section{Introduction}

Religion, in some form or another, has been around since the evolution of early man. Although in the early days, religion was mostly unorganized and varied from region to region, it gave people something greater than themselves to believe in. Worldwide, approximately eight-in-ten people identify with a religious group (Pineda, 2015). In an extensive population survey involving more than 230 countries and territories, the Pew Research Center estimated that 5.8 billion children and adults affiliated with religion around the globe, which represents $84 \%$ of the world population of the 2010 s 6.9 billion (Pew Research Centre, 2012).

Religion has a significant social and political role in the world (Kastfelt, 2015), serving as a strong source of motivation, meaning and identity to many people (Todaro, \& Smith, 2015). Notably, religion has not vanished from the public sphere and withdrawn into the private sphere. However, civil religion has become even more visible, partly caused by the global rise of a new sort of identity politics (Kastfelt, 2015). Religion is, therefore, part of people's social life. For many years, narratives of modernization and secularization have primarily shaped the theory and practice of development. Religion was viewed as a traditional and conservative force, doomed to withdraw and finally disappear from public life as society progresses towards an increasingly modernised society, and as such difficult to reconcile with or relate to development's logic of economic progress and bureaucratic rationalization. Jones and Petersen (2011) argue that development practitioners did not include religion in their policies and programmes, and development scholars did not write about religion in their books and articles. All this changed at the beginning of the millennium, and today, there is a consensus that development cooperation should also consider religion.
Globally certain characteristics have given the religious organization an added advantage when it comes to matters of development. These characteristics include the trust that religious organization have established in their communities, the leadership and respect that religious organizations command within communities, and religious organization's capacity to mobilize human, financial, and other resources (Tomalin, 2012). In addition, HochbergMiller (2015) noted that FBOs are cultural and community anchors. FBOs usually have an "open-door policy," and therefore serve as central meeting places for communities, where various issues are tackled and activities organized. In some communities, FBOs have further developed this facilitative role to include that of stabilizing landowner. Watson (2012) also pointed out that FBOs are more readily holistic in nature in their approach to development when compared to secular nonprofit organizations. The FBOs address the financial, social, political, and spiritual needs of community residents.

Kenya is predominantly a Christian country with this religion being adhered to by an estimated $84.8 \%$ of the total population. Islam is the second-largest religion, with about $9.7 \%$ of the total population subscribing to this faith (Oparanya, 2010). Further, the first words of the Kenyan national anthem and our constitution describe Kenya as a God-fearing nation. Religious freedom is provided for under the Constitution of Kenya 2010. Religion, therefore, forms a huge part of the Kenyan population, and as such, it's operation and direction not only depicts the society's behaviour but is a source of analysis of the general population. The church has played a central role in the development of this country. The Catholic Church reports that it operates 28 per cent of the nation's primary schools and over 30 per cent of its secondary schools. The Christian Health Association of Kenya and the Kenya Council of Catholic Bishops also run an extensive network of health facilities (Njoroge, 2018). However, faith actors' reach extends not just to health and education but also in the 


\section{Editon Consortium Journal of Arts, Humanities and Social Studies (ECJAHSS)}

Volume: 01 Issue: 03 | Sep -2019

ISSN: $2663-8525$

Received: 14.08.2019; Accepted 23.08.2019; published: 30.09.2019 at www.editoncpublishing.org

Ngatia mwangi et al., Editon Cons. J. Arts., Humanit. S. Stud., Double -Blind Peer Reviewed Journal

political development of the country. The church was an active participant in the countries quest for multiparty democracy in the early 1990 s and for the creation of a new constitution in the first decade of the $21^{\text {st }}$ century.

Promoting community wellbeing is usually the ultimate goal of all development programmes. The bottom-line for any effective development should be to improve the wellbeing of beneficiaries. Despite the active involvement of the church in various aspects of political development, few studies have examined the effect of church political activities on the socio-economic wellbeing of the congregation and communities at large. This gap in research limits our ability to assess the effectiveness of the church political activities in bringing about development among their congregation. It is this light that the study sought to investigate the influence of church political activities on congregation development with a specific focus on the community served by the PCEA Molo Parish.

\section{Methodology}

The study employed a descriptive design. The population of the study was 1093 individuals comprising of 13 congregation Chairpersons, 390 group leaders (officials) and 690 communicants from the PCEA Molo Parish. The appropriate sample size for the study was determined as 285 respondents using the Krejcie and Morgan (1970) Table. These respondents were proportionately distributed across the three categories that made up the study population. The study employed the systematic sampling technique to select the 285 respondents from the target population of 1093. The researcher picked every $3^{\text {rd }}$ person in the list of members, group leaders, and chairpersons until the desired sample size for each category of respondents was attained. Questionnaires were used to collect quantitative data from communicants and group leaders, and interview schedules were used to collect data from congregation chairpersons. To test the reliability and validity of research instruments, the instruments were pre- tested at the PCEA Elburgon Parish. The pilot study involved 29 respondents, equivalent to $10 \%$ of the sample size for the main study. The sample for the pilot study comprised 18 communicants, 10 group leaders, and 1 congregation chairperson from the PCEA Elburgon Parish. The researcher to sampled individuals administered the pre-tested research instruments. The data collected using questionnaires was analysed using descriptive and inferential statistics. Qualitative data was analysed thematically by organizing it into themes relevant to objectives and research questions.

\section{Literature Review}

Development is quite an elusive word. Wiseman and Brasher (2010) defined community development as a combination of economic, social, environmental, political, and cultural conditions that are essential for a given community to flourish and realize their potential. Lee and Kim (2015) defined community development as the quality of life within a given community. Atkinson (2017) asserted that community development is more than a mere aggregation of the wellbeing of individuals. It also encompasses the wellbeing of the larger super organism of the community, including collective norms and habits. It also encompasses the wellbeing that emerges from the relationships between individuals within the community, the relationship between individuals and place, as well as the relationship between individuals and cultural values.

Church political activities are actions that are inspired by the church with the view of improving the political system's capacity to manage public affairs, control conflicts, and cope with popular demands (Karimi, \& Singh, 2014). These activities are designed to improve the capacity of the political system to manage public affairs, control conflicts, and cope with popular demands (Karimi, \& Singh, 2014). They are also aimed at promoting democratic values such as improved participation of citizens in governance, 


\section{Editon Consortium Journal of Arts, Humanities and Social Studies (ECJAHSS)}

Volume: 01 Issue: 03 | Sep -2019

ISSN: $2663-8525$

Received: 14.08.2019; Accepted 23.08.2019; published: 30.09.2019 at www.editoncpublishing.org

Ngatia mwangi et al., Editon Cons. J. Arts., Humanit. S. Stud., Double -Blind Peer Reviewed Journal

and respect for fundamental freedoms and human rights (Thomas, 2011).

In the USA, Djube and Grant (2015) examined the role of the church in promoting political participation of their congregation. Results showed that the church promoted political participation in various ways, including inculcating civil skills, recruiting members into politics, holding political meetings, and clarifying political expectations. Results also showed that the church was active in influencing policies and setting political agendas. The study by Djube and Grant (2015) is however different from the current study as it was conducted in the American setting where churches might have different resources, practices, and tradition from those in Kenya. The study also identified how the church influences political activities but did not assess how church involvement in political issues affects the wellbeing of members.

In Mexico, Hale (2018) examined why some religious institutions are more successful in facilitating political participation than others. The study used a comparative case design where two states were compared: (1) Chiapas that exhibits a high level of indigenous political activism, and (2) Yacatan that experiences very little political activism. The study revealed that political activism by the church in Chiapas was mainly attributed to the highly decentralized structure adopted by the Catholic Church. On the hand, low political activism in the state of Yucatan was attributed to the centralized approach of management adopted by churches within the state. The study by Hale (2018) highlights factors that determine the impact that churches have on political issues but does not examine how church participation in politics affect the wellbeing of the community.

In the Pacific Island of Vanuatu, Matthew (2015) found that religion played a major role in shaping the political development of the country. Churches such as the Catholic,
Anglican, Pentecostal, and evangelical were directly involved in the movements for advocating for the independence of the country. These churches also played a central role in the development of the legal and political structure of national after independence. The study by Matthew (2015) details the contribution made by the church towards the political development of Vanuatu. The study, however, does not assess how political development has affected the wellbeing of communities within the country. The current study sought to establish the connection of the political development initiatives made by the church and the wellbeing of communities.

In Ghana, Asamoah (2017) examined the role played by Charismatic Clergy in political development in Ghana. Results showed that the majority of the clergy did not show interest in the political development of the country, and this their contributions were inadequate. The study recommended that to support political development, the clergy need to advice politicians and educate church members on political issues. They should also provide a platform for collaboration and reconciliation of communities. The study of Asamoah (2017) was, however, conducted in Ghana and thus, findings may not reflect the situation in Kenyan with regarding the church involvement in political issues.

In Kenya, Kenga (2014) examined the role played by religion in politics and governance. Findings revealed that there is a strong interconnection between religion and politics in Kenya. Religious institutions play a prominent role during national ceremonies, the opening of parliament, and other state functions. Religious convictions also have a strong influence on election outcomes, but the influence of religion is superseded by factors such as ethnicity, geographical location, and historical factors. Gumo, Akuloba and Omare (2015) also noted that in the 2007 General Elections, even religious leaders campaigned and supported camps for their campaign. This scenario 


\section{Editon Consortium Journal of Arts, Humanities and Social Studies (ECJAHSS)}

Volume: 01 Issue: 03 | Sep -2019

ISSN: $2663-8525$

Received: 14.08.2019; Accepted 23.08.2019; published: 30.09.2019 at www.editoncpublishing.org

Ngatia mwangi et al., Editon Cons. J. Arts., Humanit. S. Stud., Double -Blind Peer Reviewed Journal

demonstrated how, despite the spread of Christian, ethnic consciousness has resisted Christian assimilation.

Despite the failure of the church documented in the studies by Kenga (2014) and Gumo et al. (2015), the contribution of the church to political transformation in Kenya cannot be dismissed. The church was very instrumental in the movement that sought to introduce multiparty democracy as well as the movement that sought to change the constitution. In his study, Kapinde (2018) has documented how the church shaped the constitution change agenda from 1992, citing key church personalities such as Timothy Njoya, Henry Okullu, and Gideon Ireri. However, it is still not evident how the political activities of the church have influenced the wellbeing of communities. The current study sought to address this gap.

In another study, Rhodes (2015) examined the relationship between the international organization of churches in Kenya and their participation in political activities. Results revealed that churches with nationwide reach, authoritarian decision-making structures, and centralized leadership were more likely to interact with the government. It was found that churches with these features have a negotiation advantage when compared to small-decentralized churches and thus tend to get more attention from political actors. The study by Rhodes (2015) identifies factors that determine the church participation in political activities but did not examine the impact of participating in these activities on the wellbeing of members. The current study aimed to investigate this issue.

The study by Kioko (2013) examined the response of Kenyan churches to politics with a specific focus on African Inland Church (AIC) in Masinga Sub-County. The study found that the church has been silent on political issues apart from those that directly affect the church. This approach has largely been influenced by the church's doctrinal assumption regarding the relationship that exists between the church and the world. The limited political participation was also attributed to the administrative structures of the church that are characterized by high levels of ethnocentrism. The study by Kioko (2013) did not, however, examine how the AIC's response to politics affects the development of its congregation.

\section{RESULTS AND DISCUSSION}

Out of the 285 individuals that were recruited, 261 were able to complete the study by either complete their questionnaires and returning them to the researcher or completing the interview. This figure translates to a response rate of $91.6 \%$. The response rate for each category of respondents is summarized in Table 1.

\section{Table 1: Response Rate}

\begin{tabular}{|l|l|l|l|}
\hline Respondents & $\begin{array}{l}\text { Sample } \\
\text { Size }\end{array}$ & Returns & $\begin{array}{l}\text { Response } \\
\text { Rate }\end{array}$ \\
\hline Communicants & 180 & 161 & 89.4 \\
\hline Group Leaders & 102 & 97 & 95.1 \\
\hline Chairpersons & 3 & 3 & 100 \\
\hline Total & 285 & $\mathbf{2 6 1}$ & $\mathbf{9 1 . 6 \%}$ \\
\hline
\end{tabular}

Source: Field Data

\section{Respondents' Demographic Profile}

The background information of respondents was analysed in terms of gender, age, level of education, and church location. Out of the 261 respondents, 144 were female accounting for $55 \%$ of the respondents while the remaining 117 were male accounting for $45 \%$ of the sample. In terms of age, the largest proportion of the respondents (50\%) fell in the $36-50$ years age category. Another $34 \%$ of the respondents were 35 years and below, while the remaining $16 \%$ were above 50 years. From the education perspective, the largest proportion of respondents (60.2\%) had a secondary level of education. About $25.3 \%$ of the respondents had either college or university education, while $14.6 \%$ had the primary level of education or below. 


\section{Editon Consortium Journal of Arts, Humanities and Social Studies (ECJAHSS)}

Volume: 01 Issue: 03 | Sep -2019

ISSN: 2663-8525

Received: 14.08.2019; Accepted 23.08.2019; published: 30.09.2019 at www.editoncpublishing.org

Ngatia mwangi et al., Editon Cons. J. Arts., Humanit. S. Stud., Double -Blind Peer Reviewed Journal

Table 2: Respondents' Demographic Characteristics

\begin{tabular}{|c|c|c|c|}
\hline $\begin{array}{l}\text { Demographic } \\
\text { Characteristics }\end{array}$ & Categories & Frequency & $\%$ \\
\hline \multirow[t]{2}{*}{ Gender } & Male & 144 & 45 \\
\hline & Female & 117 & 55 \\
\hline \multirow[t]{3}{*}{ Age } & $\begin{array}{l}35 \text { years and } \\
\text { below }\end{array}$ & 89 & 34 \\
\hline & 36- 50 years & 131 & 50 \\
\hline & $\begin{array}{ll}\begin{array}{l}\text { Above } \\
\text { years }\end{array} & 50 \\
\end{array}$ & 41 & 16 \\
\hline \multirow{3}{*}{$\begin{array}{l}\text { Highest } \\
\text { Education } \\
\text { Level }\end{array}$} & $\begin{array}{l}\text { Primary and } \\
\text { below }\end{array}$ & 38 & 14.6 \\
\hline & Secondary & 157 & 60.2 \\
\hline & $\begin{array}{l}\text { College/ } \\
\text { University }\end{array}$ & 66 & $25 \cdot 3$ \\
\hline
\end{tabular}

\section{Congregation Socioeconomic Development at PCEA Molo} Parish

The aim of the study was to examine the effect of church political activities on congregation socioeconomic development at PCEA Molo Parish. To fulfil this objective, it was essential to understand the level of congregation socioeconomic development at PCEA Molo Parish. Both quantitative and qualitative indicators were used to assess development.

The first indicator that was assessed is happiness. As Adler (2016) pointed out, happiness is a vital indicator of the wellbeing of a given community as it is the basic aspiration of humankind. It is not always associated with income and other material resources. As displayed in Table 3, the largest percentage of respondents (70.2\%) was of the view that congregation members are generally happier than five years ago.
The second indicator that was used to measure the level of development of the congregation served by the PCEA Molo Parish was life satisfaction. The term refers to an individual's outlook and feelings regarding their own life (Adler, 2016). The concept of life satisfaction is broader than that of happiness as it more than a positive emotional state. It involves meeting certain standards and expectations that one associates with a good life. As Table 3 illustrates, the majority of the respondents $(67.8 \%)$ held the view that members of the PCEA Molo Parish congregation were generally satisfied with their lives.

Table 3: Respondents views of various aspects of Socioeconomic Development

\begin{tabular}{|l|l|l|}
\hline Statement & $\begin{array}{l}\text { True } \\
\text { (\%) }\end{array}$ & $\begin{array}{l}\text { False } \\
\text { (\%) }\end{array}$ \\
\hline $\begin{array}{l}\text { Congregation members are generally } \\
\text { happier when compared to five years } \\
\text { ago }\end{array}$ & 70.2 & 29.8 \\
\hline $\begin{array}{l}\text { Congregation members are generally } \\
\text { satisfied with the life that they are living. }\end{array}$ & 67.8 & 32.2 \\
\hline $\begin{array}{l}\text { There is generally a good relationship } \\
\text { between members of this Congregation }\end{array}$ & 86.8 & 13.2 \\
\hline $\begin{array}{l}\text { It is now easier for members of the } \\
\text { congregation to access education for } \\
\text { themselves and their kin than 5 years } \\
\text { ago. }\end{array}$ & 55.0 & 45.0 \\
\hline $\begin{array}{l}\text { The number of infant deaths among the } \\
\text { congregation has declined in the last five } \\
\text { years }\end{array}$ & 76.0 & 24.0 \\
\hline $\begin{array}{l}\text { People are generally living longer within } \\
\text { this congregation now than in the past }\end{array}$ & 50.4 & 49.6 \\
\hline $\begin{array}{l}\text { The security situation within the area has } \\
\text { improved in the last five years }\end{array}$ & 81.8 & 18.2 \\
\hline
\end{tabular}

The third indicator that was used to measure congregation development was the relationship between members of the congregation. As Table 3 demonstrates, a large proportion of respondents (86.8\%) were of the view that 


\section{Editon Consortium Journal of Arts, Humanities and Social Studies (ECJAHSS)}

Volume: 01 Issue: 03 | Sep -2019

ISSN: $2663-8525$

Received: 14.08.2019; Accepted 23.08.2019; published: 30.09.2019 at www.editoncpublishing.org

Ngatia mwangi et al., Editon Cons. J. Arts., Humanit. S. Stud., Double -Blind Peer Reviewed Journal

there is a good relationship among members of their congregation. Atkinson (2017) asserted that community wellbeing is more than a mere aggregation of the wellbeing of individuals. It also encompasses the wellbeing that emerges from the relationships between individuals within the community, the relationship between individuals and place, as well as the relationship between individuals and cultural values. Current findings suggest that there is a strong bond between members of PCEA Molo Parish congregation. Strong bonds among community members is an indicator of development as connected communities are more organized and systematic in dealing with challenges. The findings were reinforced during the interview with the congregation chairpersons. In one of the interview, Interviewee 1 stated:

"There is great love and unity among church members. This unity is what enables us to achieve what we purpose to achieve. Once we set our eyes on a particular target, all members come together to offer a different kind of support."

The next indicator of congregation development was the literacy levels within the community. As Table 3 shows, 55\% of the respondents felt that it was now easier for congregation members to access education for themselves and their kin, while $45 \%$ felt otherwise. Unlike the three previous indicators, there was a split in the respondents' views on this issue, suggesting that there might still be challenges relating to access to education. The majorities' views were supported during the interview where Interviewee 2 stated:

"We have welfare programmes that are designed to assist the less fortunate members of the church. The programmes help to cater for essential needs such as health and education of members."
The fifth indicator that was used to measure the development level in the PCEA Molo Parish congregation was infant mortality. According to Lee and Kim (2015), infant mortality is an important indicator of development as it signifies a population's access to healthcare services. Poolman (2012) also asserted that access to health is an essential indicator of development as it determines a person capability to live the life that he or she desires to live. As Table 3 shows, the majority of the respondents (76\%) were of the view that infant mortality had declined among members of their church's congregation.

Congregational development was also assessed using life expectancy of members of the congregation. As Table 3 exhibits, the opinion of the respondents was sharply divided on this issue. About $50.4 \%$ of the respondents were of the view that congregation members were living longer now than in the past, while $49.6 \%$ held contrary views. National statistics are however in support of those who reported an increase in life expectancy. Statistics indicate that the life expectancy of Kenya increased from 57 years in 1990 to 67 years in 2018 (Irungu, 2018). Increase in life expectancy is also supported by the sentiment expressed by the congregation chairpersons during the interview. For instance, Interviewee 3 narrated that:

"Each church within the Parish has a dispensary to serve members of its communities. The dispensaries have made brought health services closer to the people. In the past, people had to be taken all the way to Molo District Hospital, even if it was an emergency case. I believe the dispensary have helped save lives."

The final indicator that was used to assess congregation development is security. As Adler (2016) explained, security is a vital indicator of the development as improvement in several areas including access to economic opportunity, relationship between communities, level of organization in the community, and sense of justice. As Table 3 


\section{Editon Consortium Journal of Arts, Humanities and Social Studies (ECJAHSS)}

Volume: 01 Issue: 03 | Sep -2019

ISSN: 2663-8525

Received: 14.08.2019; Accepted 23.08.2019; published: 30.09.2019 at www.editoncpublishing.org

Ngatia mwangi et al., Editon Cons. J. Arts., Humanit. S. Stud., Double-Blind Peer Reviewed Journal

demonstrates, the majority of the respondents (81.8\%) were of the view that the security situation in their area has improved. This view is echoed by the data collected during the interview with the congregation chairperson. For instance, Interviewee 1 expressed that:

"The church has a program to engage and empower the youths. By engaging the youth, it bars them from engaging in negative behaviours such as drug and alcohol abuse, theft, and robberies."

To assess the overall development of the PCEA Molo Parish congregation, the false responses were coded as 0 , while the true responses were coded as 1 for each of the seven indicators. For each respondent, an overall score was obtained by summing up the score that he or she assigned to each indicator. A mean overall score was then arrived at by summing up the overall score for all the 258 questionnaire respondents and then dividing the figure by 258. These computations were done through SPSS. Results are presented in Table 4.

Table 4: Overall Development Score

\begin{tabular}{|l|l|}
\hline Statistic & Value \\
\hline $\mathrm{N}$ & 258 \\
\hline Mean & 5.11 \\
\hline Minimum & 3 \\
\hline Maximum & 7 \\
\hline
\end{tabular}

Source: Field Data

As displayed in Table 4, the mean overall development score was 5.11 out of a highest possible score of 7 . This implies that as per the communicants and congregation group leader, the level of development within the congregation as measured by the seven indicators was above average. The lowest overall score assigned was 3, while the highest score was 7.
Church Political Activities and Congregation Socioeconomic Development

The objective of the study was to examine the influence of church political activities on the socio-economic development of the PCEA Molo Parish congregation. To accomplish this objective, the Parish involvement in various political activities was assessed. Results are presented in Table 5.

Table 5: Respondents view of Church Involvement in various Political Activities

\begin{tabular}{|l|l|l|}
\hline Statement & $\begin{array}{l}\text { True } \\
(\%)\end{array}$ & $\begin{array}{l}\text { False } \\
\text { (\%) }\end{array}$ \\
\hline $\begin{array}{l}\text { The church encourages members of its } \\
\text { congregation to run for political office. }\end{array}$ & 28.7 & 71.3 \\
\hline $\begin{array}{l}\text { The church educates its members on } \\
\text { important political issues such as voting } \\
\text { leading to community wellbeing }\end{array}$ & 91.5 & 8.5 \\
\hline $\begin{array}{l}\text { The church is often active in advocating } \\
\text { for issues that are important to } \\
\text { members of the local community }\end{array}$ & 63.6 & 36.4 \\
\hline $\begin{array}{l}\text { The church runs programs that seek to } \\
\text { promote peace and reconciliation } \\
\text { among various social groupings within } \\
\text { the community }\end{array}$ & 70.2 & 29.8 \\
\hline $\begin{array}{l}\text { The church is actively involved in } \\
\text { shaping the policies and laws that affect } \\
\text { members of the congregation }\end{array}$ & 74.4 & 25.5 \\
\hline $\begin{array}{l}\text { The church encourages the } \\
\text { development of values that are } \\
\text { essential to political development such } \\
\text { as integrity }\end{array}$ & 70.9 & 29.1 \\
\hline $\begin{array}{l}\text { The church usually push for the active } \\
\text { involvement of congregants in key } \\
\text { governance issues }\end{array}$ & 40.3 & 59.7 \\
\hline
\end{tabular}

The first issue that was examined relating to church political activities was whether the church encouraged its member to run for political office. This issue was found on 


\section{Editon Consortium Journal of Arts, Humanities and Social Studies (ECJAHSS)}

Volume: 01 Issue: 03 | Sep -2019

ISSN: $2663-8525$

Received: 14.08.2019; Accepted 23.08.2019; published: 30.09.2019 at www.editoncpublishing.org

Ngatia mwangi et al., Editon Cons. J. Arts., Humanit. S. Stud., Double -Blind Peer Reviewed Journal

the rationale that people who get elected into political position have a significant influence on the level of development in the area as they are directly involved in the setting of policies, distribution of resources, and providing oversight. Consequently, a church can promote development by supporting their own to run for political position. As Table 5 discloses, the majority of the respondents (71.3\%) negated the claim that their church encourages members to run for political positions. This finding agrees is consistent with the study by Kioko (2013), which found that many Christians have developed the perception that politics is "dirty" and that Christians should not get involved. The study found that many churches tend to stay away from elective politics. A few churches endorse candidates but do not gloom members of their congregation to take up political leadership. Kenga (2014) also found that churches were characterized by high levels ethnocentrism that barred the church from taking a common position on political issues.

The second issue that was assessed was educating members of the congregation on political issues. It is based on the rationale that to promote development in its congregation and the larger community; the church should ensure that its members are enlightened about political issues that are likely to have an impact on their wellbeing. As displayed in Table 5, the largest percentage of the respondents (91.5\%) acknowledged that their church educates members on important political issues. This position was also reinforced during the interview with congregation chairpersons. Interviewee 3 narrated that:

"The church educates members on the importance of voting and how it affects their lives. The church also urges members to vote wisely based on principles and values rather than ethnicity that has been the norm."

Interviewee 1 also expressed that:

"The church educates people on various issues, including voting and various programs offered by the government. In the past few Sundays, the church has been active in educating members about the Huduma Namba and urging them to register. A lot of misinformation had been spread about this programme."

The next issue that was assessed was church involvement in advocating for matters that are important to members. This issue was founded on the rationale that the church can provide a platform where community members can voice their concern and present their concerns to people in government. As Table 5 displays, $63.6 \%$ of the respondents asserted that their church is actively involved in agitating for issues that are vital to members. The finding is congruent with the study by Hale (2018), who found that churches in Mexico were involved in political activism. Churches that had decentralized organizational structure were more active than those with a centralized bureaucratic structure were. The PCEA has a relatively decentralized structure where most activities are planned and implemented at the Parish or church level. This may explain the active involvement of the church in political activism.

Another issue that was examined was the church involvement in promoting peace and reconciliation. Politics often creates division and lead to the emergence of conflict. The church can play a role in promoting peace and reconciling communities that have been divided by political competition. As Table 5 demonstrates, the majority of the respondents (70.2\%) confirmed that their church was actively involved in running programmes that seek to promote peace and reconciliation. This position was reinforced by qualitative data from the interviews with congregation chairpersons. Interviewee 3 said that:

"The church has played a significant role in bringing together communities living in the area. These communities have been significantly affected by political tension and violence in the 


\section{Editon Consortium Journal of Arts, Humanities and Social Studies (ECJAHSS)}

Volume: 01 Issue: 03 | Sep -2019

ISSN: 2663-8525

Received: 14.08.2019; Accepted 23.08.2019; published: 30.09.2019 at www.editoncpublishing.org

Ngatia mwangi et al., Editon Cons. J. Arts., Humanit. S. Stud., Double-Blind Peer Reviewed Journal

past. The church has prioritised build harmony and create a peaceful coexistence within the region."

Next, the study examines the level of the parish involvement in the shaping of policies and laws. Policies and laws are a major component of politics and have a significant implication on development. Consequently, a church can promote development in its community by ensuring the right policies and laws are created. As Table 5 shows, the majority of the respondents $(74.4 \%)$ confirmed that the church was actively involved in shaping policies and laws that affect members of the congregation. This view was also echoed during the interview with the chairperson. Interviewee 1 specified that:

"The PCEA Church has always been active in shaping laws and policies at the national and county levels. This church was very vocal in the clamour for creation of a new constitution."

The study also interrogated that the contribution of the church in terms of developing values that are essential to political development. This item was founded on the rationale that one of the ways in which the church can influence politics is by inculcating values such as integrity, transparency, and accountability. As Table 5 shows, the largest proportion of respondents (70.9\%) affirmed that their church encourages the development of values that are essential to political development. Similar sentiments were also captured during the interview. Interviewee 3 expressed that:

"Church leaders always educate congregants on the need to elect good leaders. They try to explain to the congregation the expectations that the church has when it comes to selecting a leader. Members are urged to elect leaders who are honest, transparent, and God-fearing."
The final issue that was examined was whether the church encourages members to engage in governance issues. Involvement of citizens in governance is one of the features of a developed society. Church can, therefore, promote developing by urging their members to be active participants in governance issues. It can encourage its members to attend citizen participation forums, especially those involved in the formulation of county budgets and policies. As Table 5 demonstrates, 59.7\% negated the claim that the church usually pushes for the active involvement of congregants in key governance issue. This finding agrees with the study by Kioko (2013), which found that many churches in Kenya stay clear of political and governance issue because of the ideology that defines politics as worldly things.

An aggregate score for all church political activities was computed to provide an overview of the parish's involvement in political activities. The score for each respondent was obtained by summing up the score for all the seven political issues. Results are presented in Table 6.

Table 6: Statistics for Overall Church Political Activities Score

\begin{tabular}{|l|l|}
\hline Statistic & Value \\
\hline $\mathrm{N}$ & 258 \\
\hline Mean & 4.92 \\
\hline Minimum & 2 \\
\hline Maximum & 7 \\
\hline
\end{tabular}

Source: Field Data

As Table 6 shows, the mean overall score for church political activities was 4.92 out of a highest possible score of 7. This implies that in the respondents' view, the parish involvement in political activities was above average. The minimum score assigned was 2 , while the maximum score was 7. 


\section{Editon Consortium Journal of Arts, Humanities and Social Studies (ECJAHSS)}

Volume: 01 Issue: 03 | Sep -2019

ISSN: $2663-8525$

Received: 14.08.2019; Accepted 23.08.2019; published: 30.09.2019 at www.editoncpublishing.org

Ngatia mwangi et al., Editon Cons. J. Arts., Humanit. S. Stud., Double -Blind Peer Reviewed Journal

\section{Correlation between Church Political Activities and}

\section{Congregation Socioeconomic Development}

To establish the influence of church political activities on congregation socioeconomic development, data on overall church political activities score was correlated with data on overall congregation development score. Results are presented in Table 7.

Table 7: Results of Correlation between Church Political Activities and Congregation Development

\begin{tabular}{|l|l|l|}
\hline \multicolumn{2}{|l|}{} & $\begin{array}{l}\text { Congregation } \\
\text { Development } \\
\text { score }\end{array}$ \\
\hline \begin{tabular}{l} 
Church $\begin{array}{l}\text { Economic } \\
\text { Activities score }\end{array}$ \\
\cline { 2 - 3 }
\end{tabular} & $\begin{array}{l}\text { Correlation } \\
\text { coefficient }(r)\end{array}$ & $.418^{* *}$ \\
\cline { 2 - 3 } & P-value & .014 \\
\cline { 2 - 3 } & $\mathrm{N}$ & 258 \\
\hline
\end{tabular}

Source: Field Data

As Table 7 exhibits, the correlation analysis gave a coefficient of 0.418 for the relationship between church political activities and congregation development. Since the coefficient is positive, it means that the relationship between the two variables is positive. This implies that increasing the churches' involvement in political activities would result in an increase in the level of congregation development. The $p$-value for the relationship between church political activities and congregation development was 0.014 . Since the value is less than 0.05 , it implies that the relationship between church political activities and congregation development is statistically significant. These results lead to the conclusion that church political activities have a positive and statistically significant influence on congregation development at the PCEA Molo Parish.

\section{Conclusions}

Findings suggest that church political activities have a positive and significant influence on congregation socioeconomic development in the PCEA Molo Parish. This denotes that increasing church political activities would increase the level of congregation development. To increase the level of socio-economic development among its congregants, the study recommends that the PCEA Molo Parish should consider encouraging and supporting members of its congregation to run for political office. This is the only way that can guarantee that the area gets good and upright leaders that can deliver development goals. The parish should also encourage its congregant to actively engage in governance issue particular in public participation forums that seek to determine budget allocation and formulation of laws. The current study was confined to PCEA Molo Parish. To increase the generalizability of findings, future studies should consider replicating this study in other areas and using other churches. The study was also done in a mainstream conventional church. For more conclusive results, conventional and non-conventional church organizations should be studied. 


\section{Editon Consortium Journal of Arts, Humanities and Social Studies (ECJAHSS)}

Volume: 01 Issue: 03 | Sep -2019

ISSN: 2663-8525

Received: 14.08.2019; Accepted 23.08.2019; published: 30.09.2019 at www.editoncpublishing.org

Ngatia mwangi et al., Editon Cons. J. Arts., Humanit. S. Stud., Double -Blind Peer Reviewed Journal

\section{References}

Adler, A. (2016). Teaching well-being increases academic performance: Evidence from Bhutan, Mexico, and Peru (Doctoral dissertation). University of Pennsylvania, USA.

Asamoah, M. (2017). The role of the Penteo/Charismatic clergy in the political health development in Ghana. Journal of Religious Health, 2(1), 41- 49.

Atkinson, S. (2017). What is community wellbeing? Conceptual review. Liverpool, UK: University of Liverpool.

Djube, P., \& Grant, T. (2001). Religious institutions and political participation in America. Journal of the Scientific Study of Religion 40(2), 303-14.

Gumo, S., Akuloba, A., \& Omare, S. (2015). Religion and politics in contemporary Kenya (Unpublished thesis). Maseno University, Kenya.

Hale, C. (2018). Religious institutions and collective action: The Catholic Church and political activism in indigenous Chiapas and Yucatan. Politics and Religion, 11(1), 27-54.

Irungu, G. (2018). Improved life expectancy lifts Kenya's ranking. Business Daily. Retrieved from https://www.businessdailyafrica.com/news/Improved-life-expectancy-lifts-Kenya-sranking/539546-4904926-vx4n8yz/index.html.

Jones, B., \& Petersen, M. J. (2011). Instrumental, narrow, normative? Reviewing recent work on religion and development. Third World Quarterly, 32(7), 1291-1306.

Kapinde, S. (2018). The church and constitutional reforms in Kenya, 1992-2002: A retrospective-historical analysis. European Scientific Journal, 14(5), 216-240.

Kastfelt, N. (2015). Hvad vil Boko Haram? RÆESON, 50-53.

Karimi, M., \& Singh, S. (2014). Political development concept by looking briefly at Iran's Mohammad Reza Pahlavi rule. Journal of Public Administration and Governance, 4(4), 67- 78.

Kenga, C. (2014). The role of religion in politics and governance in Kenya (Unpublished thesis). University of Nairobi, Kenya.

Kioko, D. (2013). The response of the Africa Inland Church to politics in Masinga District: 1975-2010 (Unpublished thesis). Kenyatta University, Kenya.

Lee, S., \& Kim, Y. (2015). Searching for the meaning of community well-being. Switzerland, SZ: Springer Publishing.

Matthew, C. (2015). Christianity and the shaping of Vanuatu's social and political development. Journal for the Academic Study of Religion, 28(1), 24- 41.

Hochberg-Miller, M. (2015). Models of faith: The role of Faith-Based Organizations in international development. (MA IDS Thesis Projects: Portland, Concordia University).

Njoroge, L. (2018). A trailblazer who moulded the 'Jitegemea' spirit. Nairobi: Jitegemea Press Retrieved from https://www.nation.co.ke/oped/opinion/Trailblazer-who-molded-the--Jitegemea-spirit/440808-4589826-9p6dsb/index.html 


\section{Editon Consortium Journal of Arts, Humanities and Social Studies (ECJAHSS)}

Volume: 01 Issue: 03 | Sep -2019

ISSN: $2663-8525$

Received: 14.08.2019; Accepted 23.08.2019; published: 30.09.2019 at www.editoncpublishing.org

Ngatia mwangi et al., Editon Cons. J. Arts., Humanit. S. Stud., Double -Blind Peer Reviewed Journal

Oparanya, W. (2010, August 31) "2009 Population \& Housing Census Results". Archived from the original on 10 August 2013. Retrieved 17 May 2018. Ministry of State for Planning. knbs.or.ke

Pew Research Center (2012). The global religious landscape. Retrieved on $16^{\text {th }}$ July 2019 from https://www.pewforum.org/2012/12/18/global-religious-landscape-exec/.

Pineda, D. (2015). Strategies for church growth: Tools for effective mission and evangelism. Ventura, CA: Regal Books

Poolman, C. (2012). Humanity in the capabilities approach to development. POLIS Journal, 7(2), 366- 408.

Rhodes, C. (2015). Political Christianity: Internal organization, preferences and church political activity (Unpublished thesis). Harvard University, UK.

Thomas, G. (2011). What is political development? A constitutional perspective. The Review of Politics, 73(2), 275- 294.

Todaro, M., \& Smith, S. (2015). Economic development (12 ${ }^{\text {th }}$ Edn.). New York, NY: Pearson.

Tomalin, E. (2012). Thinking about faith-based organizations in development: Where have we got to and what next? Journal of Development in Practice, 22(6), 689-703.

Watson, C. (2012). Faith-based organizations and their contributions to society (Unpublished thesis). Southern Illinois University, USA.

Wiseman, J., \& Brasher, K. (2010). Community wellbeing, art and culture challenges and opportunities for local communities and local governments. Proceedings of the Expanding Cultures' conference, Melbourne. 